\title{
Fatty acids, cholesterol, oxidative rancidity, and color of irradiated shrimp
}

\author{
Ácidos graxos, colesterol, rancidez oxidativa e cor de camarões irradiados
}

\author{
Virgínia Kelly Gonçalves ABREU ${ }^{1 *}$, Ana Lúcia Fernandes PEREIRA ${ }^{1}$, Tatiana Fontoura VIDAL ${ }^{1}$, \\ Jorge Fernando Fuentes ZAPATA ${ }^{1}$, Manoel Alves de SOUSA NETO², Ednardo Rodrigues de FREITAS ${ }^{3}$
}

\begin{abstract}
The effect of gamma irradiation (0, 2, 4, and $6 \mathrm{kGy}$ doses) applied to frozen and packed headed shrimp on the fatty acid profile, cholesterol content, and lipid and color stability was evaluated. Myristic acid was higher in shrimp irradiated with 4 and $6 \mathrm{kGy}$ and palmitic acid was higher in samples irradiated with 2 and $6 \mathrm{kGy}$ compared to non-irradiated samples. Stearic and behenic acids were lower in shrimp irradiated with $6 \mathrm{kGy}$ compared to non-irradiated shrimp. With regard to non-irradiated shrimp, palmitoleic, oleic, and linoleic acids and total monounsaturated fatty acids were higher in shrimp irradiated with $6 \mathrm{kGy}$. Saturated fatty acid and cholesterol contents in irradiated samples were not different from those in non-irradiated shrimp. Lipid oxidation was higher in samples irradiated with 2,4 , and $6 \mathrm{kGy}$. Redness and yellowness of cooked shrimp were higher in samples irradiated with $6 \mathrm{kGy}$ than in those in non-irradiated samples. The application of irradiation in doses up to $6 \mathrm{kGy}$ on frozen and packed headed shrimp does not affect negatively the fatty acid profile, cholesterol content, and lipid and color stability.

Keywords: irradiation; fatty acids; TBARS, $L^{*}, a^{*}, b^{*}$.
\end{abstract}

\section{Resumo}

Foi estudado o efeito da radiação gama (doses de 0, 2, 4 e $6 \mathrm{kGy}$ ) em caudas de camarão congeladas e embaladas, sobre os conteúdos de ácidos graxos e colesterol, bem como sobre a estabilidade dos lipídios e da cor. Com relação ao camarão não irradiado, os ácidos mirístico e palmítico apresentaram maiores valores nos camarões irradiados com 4 e 6 kGy e com 2 e 6 kGy, respectivamente. Os ácidos esteárico e behênico foram menores nas amostras irradiadas com $6 \mathrm{kGy}$ em relação às não irradiadas. Os ácidos palmitoleico, oleico, linoleico e o total de ácidos graxos monoinsaturados foram maiores nos camarões irradiados com $6 \mathrm{kGy}$ do que naqueles não irradiados. Para o total de ácidos graxos saturados e conteúdo de colesterol, as amostras irradiadas não diferiram daquelas não irradiadas. A oxidação lipídica aumentou com a irradiação. Os componentes de cor $\mathrm{a}^{*} \mathrm{e} \mathrm{b}^{*}$ do camarão cozido foram maiores com 6 kGy. A irradiação em doses de até 6 kGy não afetou negativamente o perfil de ácidos graxos, o nível de colesterol e a estabilidade dos lipídios e da cor das caudas de camarões.

Palavras-chave: irradiação; ácidos graxos; TBARS, $L^{*}, a^{*}, b^{*}$.

\section{Introduction}

Shrimp farming is the sector of the aquaculture that shows the highest growing potential worldwide. Brazilian cultured shrimp production is an important economical activity in the northeast region of the country. Currently, Penaeus vannamei, the most intensively exploited species in the region, has reached high economic value at the local and external market levels (BARBIERI JÚNIOR; OSTRENSKY NETO, 2002; CARVALHO et al., 2005).

Shrimp is a rich source of protein, and its lipids are highly unsaturated compared to those of red meat. The most important unsaturated fatty acids in shrimp are eicosapentaenoic (20:5, EPA) and docosahexaenoic (22:6, DHA), which are also considered as essential fatty acids. Moreover, shrimp is a good source of minerals such as calcium, and it is also considered a high cholesterol food (MOURA; TENUTA-FILHO, 2002).
Foods from animal origin are the main sources of cholesterol in the human diet. Cholesterol is a stable compound that in the food is closely associated with others lipids. However, lipid oxidation can lead to oxidation of cholesterol (NAM et al., 2001).

Irradiation of lipids and fats may produce carbonyl groups and other oxidation products, such as peroxides. It is generally assumed that irradiation in the presence of oxygen increases oxidative changes. Rancidity is a sensory effect markedly perceptible when lipids are irradiated in the presence of oxygen (SANTOS et al., 2003; VENUGOPAL; DOKE; THOMAS, 1999).

Color is an important quality attribute that influences consumer acceptance of meat and fishery products. Free radicals generated by irradiation can react with myoglobin or carotenoid pigments leading to discoloration of several food products (LAWRIE, 2005).

${ }^{1}$ Departamento de Tecnologia de Alimentos, Universidade Federal do Ceará - UFC, Av. Mr. Hull, n. 2977, CEP 60356-001, Fortaleza - CE, Brasil, E-mail: vkellyabreu@gmail.com

${ }^{2}$ EMBRAPA Agroindústria Tropical, Fortaleza - CE, Brasil

${ }^{3}$ Departamento de Zootecnia, Universidade Federal do Ceará - UFC, Fortaleza - CE, Brasil

${ }^{*}$ A quem a correspondência deve ser enviada 
Although irradiation is considered an effective technology in food preservation, it can cause significant changes in product quality, such as lipid oxidation and other chemical changes. Since fish lipids are more unsaturated as compared to those of red meat, their sensitivity to irradiation is one of the parameters that has been considered to optimize radiation doses used for fish preservation (LAKSHMANAN et al., 1999).

Thus, the objective of this study was to verify the effect of gamma irradiation applied on frozen and packed headed shrimp on fatty acid and cholesterol contents, as well as on lipid and color stability.

\section{Materials and methods}

\subsection{Experimental design and preparation of shrimp samples}

In this study a complete randomized design $(4 \times 5)$ with four irradiation doses $(0,2,4$, and $6 \mathrm{kGy})$ and five replicates was used.

Fresh medium size (80 to 100 tails.kg-1 $)$ headed shrimp, Penaeus vannamei, was obtained from a local industry operating in accordance with the Brazilian Federal Inspection Service (BRASIL, 2001) and transported to the laboratory in a thermal container (shrimp and ice at the rate of 1:1). After separating from ice, the shrimp was divided into $300 \mathrm{~g}$ portions, packed in polyethylene $(0.15 \mathrm{~mm}$ thick) bags and added of $200 \mathrm{~mL}$ of water. The bags were then sealed, packed in cardboard boxes $(14.5 \times 11.0 \times 4.5 \mathrm{~cm}$, internally lined with polyethylene film) and frozen at $-30{ }^{\circ} \mathrm{C}$ for 12 hours. Those packages were considered the Experimental Unit (EU) for the study.

Five frozen EU were then packed in four cardboard master boxes $(18.0 \times 27.0 \times 36.0 \mathrm{~cm})$ and stored at $-20^{\circ} \mathrm{C}$ until irradiation. Each box was then irradiated under $\mathrm{a}^{60} \mathrm{Cobalt}$ source with doses of 0, 2, 4, or $6 \mathrm{kGy}$ at a dose rate of $1500 \mathrm{~Gy} / \mathrm{hour}$.

EUs were then analyzed for fatty acid and cholesterol concentrations, lipid oxidation, and color stability.

\subsection{Analysis of irradiated shrimp}

For fatty acid composition analysis, EUs were ground into a homogenous mass using a domestic food processor. About $10 \mathrm{~g}$ of shrimp homogenate were freeze-dried for 24 hours. The dehydrated shrimp samples were then vacuum-packed in nylon-polyethylene bags and stored at $1{ }^{\circ} \mathrm{C}$ until preparation in the form of fatty acid methyl esters.

The fatty acids were extracted from freeze dried shrimp and converted into methyl esters according to the procedure described by Rule et al. (2002). Chromatographic analyses were performed using a gas chromatograph (VARIAN CP 3380, Walnut Creek, USA), equipped with fused silica capillary column $(100 \mathrm{~m} \times 0.25 \mathrm{~mm}$ i.d.) and a Flame Ionization Detector (FID). Hydrogen was used as the carrier gas at a flow rate of $1.5 \mathrm{~mL} /$ minute. The initial temperature of the column was set at $160^{\circ} \mathrm{C}$ and was increased to $240^{\circ} \mathrm{C}$ at a rate of $3.5^{\circ} \mathrm{C} /$ minute, and then it was held at $240{ }^{\circ} \mathrm{C}$ for an additional 10 minutes period. The detector and injection port were maintained at $250{ }^{\circ} \mathrm{C}$.
Injection of $1 \mu \mathrm{L}$ samples was performed in the split less mode. The fatty acids were identified by the comparison of their retention time with those of authenticated standard (Supelco). The fatty acid methyl ester standard mixture used in this study contained: caprylic acid (C8:0), capric acid (C10:0), lauric acid (C12:0), myristic acid (C14:0), palmitic acid (C16:0), palmitoleic acid (C16:1), stearic acid (C18:0), oleic acid (C18:1), linoleic acid (C18:2), linolenic acid (C18:3), arachidic acid (C20:0), eicosenoic acid (C20:1), behenic acid (C22:0), and erucic acid (C22:1). The identification of some unknown peaks were further confirmed by gas chromatography with mass spectroscopy detection (SHIMADZU GCMS-QP 2010, Kyoto, Japan) as arachidonic (C20:4), eicosapentaenoic (C20:5), and docosahexanoic (C22:6) acids. The fatty acid peak areas were quantified and expressed as a percentage of total methyl esters.

The determination of cholesterol in irradiated shrimp was carried out by direct saponification of freeze dried shrimp followed by gas chromatography analysis according to the method developed by Botsoglou et al. (1998). A $1 \mu \mathrm{L}$ aliquot from the saponified extract was injected on a fused silica capillary column, $30 \mathrm{~m} \times 0.53 \mathrm{~mm}$ i.d. and coated with SPB-1 film thickness of $1.0 \mu \mathrm{m}$. The column temperature was programmed from 250 to $300{ }^{\circ} \mathrm{C}$ at $10{ }^{\circ} \mathrm{C} /$ minute and held at $300{ }^{\circ} \mathrm{C}$ for 15 minutes. The injection port and flame ionization detector temperatures were set at $300^{\circ} \mathrm{C}$. Hydrogen carrier gas was set at $3.4 \mathrm{~mL} /$ minute. All injections were performed in a split less mode. The cholesterol was identified by comparing the retention time to that of an authenticated standard. The quantification was done against an external standard from a curve plotted with the amount of cholesterol and peak area. The cholesterol concentrations were expressed as mg cholesterol. $100 \mathrm{~g}^{-1}$ sample.

Lipid oxidation was measured by determining thiobarbituric acid reactive substances (TBARS) in an acidic extract using the method described by Raharjo, Sofos and Schmidt (1992) modified by Facco (2002). The rose-pink color produced by the reaction between malondialdehyde (MDA) and 2-thiobarbituric acid was measured using a spectrophotometer (Ultrospec 2000 Pharmacia/ Biotech, Cambridge, England) at $531 \mathrm{~nm}$. Lipid oxidation was expressed as TBARS numbers (mg MDA. $\mathrm{kg}^{-1}$ sample).

The color parameters were determined using a Minolta CR300 colorimeter (Tokyo, Japan) operating in the CIE system, were $L^{*}$ is lightness, $a^{*}$ is redness, and $b^{*}$ is yellowness. The colorimeter was standardized using a white tile (Illuminant D65) and the measurements were made through a $8 \mathrm{~mm}$ port/viewing area (MINOLTA, 1998) on the surface of cooked (boiled in a $3 \% \mathrm{NaCl}$ solution for 2 minutes) and peeled shrimp.

The results were submitted to analysis of variance by PROC ANOVA (STATISTICAL..., 2000), and the Student-Newman-Keuls (SNK) test was used to compare mean values (5\% of probability).

\section{Results and discussion}

In this study, a total of 14 fatty acids were identified in nonirradiated or irradiated headed shrimp (Table 1). The predominant fatty acids found were stearic (18:0) and palmitic (16:0). These results are in agreement with those of Perez-Velazquez et al. (2003), who also reported that these fatty acids were the most abundant in pacific white shrimp (Litopenaeus vannamei). 
Table 1. Fatty acids (mean percentages) of headed shrimp (P. vannamei) measured after freezing, packaging, and irradiating $\left({ }^{60} \mathrm{Co}\right)$ with 0,2 , 4 , or 6 kGy doses ${ }^{(1)}$.

\begin{tabular}{lrrrr}
\hline $\begin{array}{c}\text { Fatty acids } \\
(\%)\end{array}$ & \multicolumn{4}{c}{ Dose (kGy) } \\
\cline { 2 - 5 } C14:0 & \multicolumn{1}{c}{2} & \multicolumn{1}{c}{4} & \multicolumn{1}{c}{6} \\
\hline $\mathrm{C} 16: 0$ & $0.84^{\mathrm{b}} \pm 0.19$ & $1.20^{\mathrm{b}} \pm 0.41$ & $1.52^{\mathrm{a}} \pm 0.26$ & $1.35^{\mathrm{a}} \pm 0.16$ \\
$\mathrm{C} 18: 0^{(3)}$ & $41.24^{\mathrm{b}} \pm 0.52$ & $24.44^{\mathrm{a}} \pm 0.56$ & $21.59^{\mathrm{c}} \pm 0.95$ & $24.70^{\mathrm{a}} \pm 0.91$ \\
$\mathrm{C} 20: 0$ & $42.30^{\mathrm{a}} \pm 1.57$ & $40.89^{\mathrm{a}} \pm 1.39$ & $37.72^{\mathrm{b}} \pm 1.51$ \\
$\mathrm{C} 22: 0^{(4)}$ & $0.60^{\mathrm{a}} \pm 0.03$ & $0.62^{\mathrm{a}} \pm 0.01$ & $0.65^{\mathrm{a}} \pm 0.06$ & $0.58^{\mathrm{a}} \pm 0.02$ \\
$\mathrm{C} 16: 1^{(5)}$ & $0.80^{\mathrm{b}} \pm 0.11$ & $0.07^{\mathrm{b}} \pm 0.02$ & $0.07^{\mathrm{b}} \pm 0.02$ & $0.03^{\mathrm{b}} \pm 0.01$ \\
$\mathrm{C} 18: 1^{(6)}$ & $8.51^{\mathrm{b}} \pm 0.55$ & $6.75^{\mathrm{b}} \pm 1.39$ & $7.92^{\mathrm{b}} \pm 1.45$ & $12.15^{\mathrm{a}} \pm 1.73$ \\
$\mathrm{C} 20: 1$ & $0.26^{\mathrm{a}} \pm 0.03$ & $0.28^{\mathrm{a}} \pm 0.02$ & $0.25^{\mathrm{a}} \pm 0.05$ & $0.33^{\mathrm{a}} \pm 0.09$ \\
$\mathrm{C} 22: 1^{(7)}$ & $0.10^{\mathrm{a}} \pm 0.04$ & $0.14^{\mathrm{a}} \pm 0.01$ & $0.14^{\mathrm{a}} \pm 0.02$ & $0.10^{\mathrm{a}} \pm 0.04$ \\
$\mathrm{C} 18: 2^{(8)}$ & $5.46^{\mathrm{b}} \pm 0.35$ & $4.79^{\mathrm{b}} \pm 0.40$ & $4.23^{\mathrm{b}} \pm 0.91$ & $6.95^{\mathrm{a}} \pm 1.48$ \\
$\mathrm{C} 18: 3^{(9)}$ & $0.32^{\mathrm{a}} \pm 0.01$ & $0.32^{\mathrm{a}} \pm 0.02$ & $0.27^{\mathrm{a}} \pm 0.05$ & $0.26^{\mathrm{a}} \pm 0.04$ \\
$\mathrm{C} 20: 4$ & $1.61^{\mathrm{a}} \pm 0.17$ & $1.54^{\mathrm{a}} \pm 0.09$ & $1.37^{\mathrm{a}} \pm 0.31$ & $1.68^{\mathrm{a}} \pm 0.40$ \\
$\mathrm{C} 20: 5$ & $4.86^{\mathrm{a}} \pm 0.56$ & $4.56^{\mathrm{a}} \pm 0.28$ & $4.22^{\mathrm{a}} \pm 1.05$ & $4.99^{\mathrm{a}} \pm 1.32$ \\
$\mathrm{C} 22: 6$ & $3.07^{\mathrm{a}} \pm 0.03$ & $3.02^{\mathrm{a}} \pm 0.49$ & $2.60^{\mathrm{a}} \pm 0.59$ & $2.69^{\mathrm{a}} \pm 0.63$ \\
\hline
\end{tabular}

${ }^{(1)}$ Mean values with different letters within a row are significantly different $(\mathrm{p}<0.05)$ by SNK test, $\mathrm{n}=5$; ${ }^{(2)}$ Quadratic effect $\left(\mathrm{y}=0.82+0.29 \mathrm{x}-0.03 \mathrm{x}^{2}, \mathrm{R}^{2}=0.49\right)$, being $\mathrm{y}=$ miristic acid concentration; $\mathrm{x}=$ irradiation dose; $\mathrm{R}^{2}=$ determination coefficient; ${ }^{(3)}$ Quadratic effect $\left(\mathrm{y}=41.35+0.95 \mathrm{x}-0.26 \mathrm{x}^{2} ; \mathrm{R}^{2}=0.62\right) ;{ }^{(4)}$ Linear effect $(\mathrm{y}=0.11-0.01 \mathrm{x}$; $\left.\mathrm{R}^{2}=0.45\right) ;{ }^{(5)}$ Quadratic effect $\left(\mathrm{y}=0.80-0.17 \mathrm{x}+0.04 \mathrm{x}^{2} ; \mathrm{R}^{2}=0.78\right) ;{ }^{(6)}$ Quadratic effect $\left(\mathrm{y}=8.51-1.65 \mathrm{x}+0.37 \mathrm{x}^{2} ; \mathrm{R}^{2}=0.73\right) ;{ }^{(7)}$ Quadratic effect $\left(\mathrm{y}=0.10+0.03 \mathrm{x}-0.004 \mathrm{x}^{2} ;\right.$ $\left.\mathrm{R}^{2}=0.30\right) ;{ }^{(8)} \mathrm{Quadratic}$ effect $\left(\mathrm{y}=5.61-1.07 \mathrm{x}+0.21 \mathrm{x}^{2} ; \mathrm{R}^{2}=0.54\right) ;{ }^{(9)}$ Linear effect $\left(y=0.33-0.01 x ; R^{2}=0.40\right)$

Myristic acid (14:0) was higher $(\mathrm{p}<0.05)$ in headed shrimp irradiated with 4 and $6 \mathrm{kGy}$ doses compared to non-irradiated shrimp. Palmitic $(16: 0)$ acid was higher $(\mathrm{p}<0.05)$ in samples irradiated with 2 and $6 \mathrm{kGy}$ doses than those in non-irradiated. Stearic acid (18:0) showed lower values in shrimp samples irradiated with $6 \mathrm{kGy}$ (Table 1).

Similar observations have been reported by Lakshmanan et al. (1999), who observed higher myristic and palmitic acids values and lower stearic acid values with higher irradiation doses in studies on lipid stability in irradiated Indian mackerel.

Palmitoleic (C16:1), oleic (18:1), and linoleic (C18:2) acids were higher $(\mathrm{p}<0.05)$ in shrimp irradiated with $6 \mathrm{kGy}$ compared to non-irradiated shrimp (Table 1). Yilmaz and Geçgel (2007) also found higher values of palmitoleic (C16:1) and linoleic (C18:2) acids in ground beef using higher irradiation doses (5 and $7 \mathrm{kGy}$ ). For the oleic (18:1) acid, several studies with irradiated meat showed significant increases of this fatty acid (ALFAIA et al., 2007; CHEN et al., 2007).

A reduction $(\mathrm{p}<0.05)$ of behenic $(22: 0)$ acid in shrimp samples with increasing irradiation doses was observed (Table 1). However, Yilmaz and Geçgel (2007) using 1, 3, 5, and $7 \mathrm{kGy}$ irradiation in refrigerated ground beef doses observed a reduction of behenic acid only with the $7 \mathrm{kGy}$ dose.

Arachidic (20:0), eicosenoic (20:1), erucic (22:1), linolenic (18:3), arachidonic (20:4), EPA (20:5), and DHA (22:6) acids were not affected $(p>0.05)$ by irradiation (Table 1$)$. These results are in agreement with those of Alfaia et al. (2007), who did not observe significant changes in these fatty acids in irradiated frozen lamb meat.

Moreover, according to the regression analysis, palmitic (16:0), arachidic (20:0), eicosenoic (20:1), arachidonic (20:4), EPA (20:5), and DHA (22:6) acids were not significantly $(p>0.05)$ affected by irradiation of frozen and headed shrimp. However, behenic (22:0) and linolenic (18:3) acids were affected $(\mathrm{p}<0.05)$ by irradiation in the form of a linear effect according to equations 4 and 9 , respectively, as shown in the footnotes of Table 1.

Myristic (14:0), palmitoleic (C16:1), stearic (18:0), oleic (18:1), linoleic (C18:2), and erucic (22:1) acids were also affected $(\mathrm{p}<0.05)$ by irradiation as a quadratic effect according to equations $2,3,5,6,7$, and 8 , respectively (footnotes, Table 1 ). Thus, myristic (14:0), stearic (18:0) and erucic (22:1) acids showed maximum values at 4.40, 1.82, and $2.98 \mathrm{kGy}$ irradiation doses, respectively. Higher dose values provided reduction in the concentrations of these fatty acids. Palmitoleic (C16:1), oleic (18:1), and linoleic (C18:2) acids showed the lowest values at the irradiation doses of $2.28,2.19$, and $2.54 \mathrm{kGy}$, respectively. Doses higher than these increase the concentration of these fatty acids (Table 1).

Total Saturated Fatty Acid (SFA) values in irradiated shrimp were not different $(p>0.05)$ from those in non-irradiated shrimp. According to the regression analysis, a quadratic effect $\left(\mathrm{R}^{2}=0.32\right)$ was observed. Thus, SFA increased with irradiation up to the dose of $1.10 \mathrm{kGy}$. Higher dose values reduced SFA content (Table 2).

SFA values are associated with the incidence of coronary heart disease due to the increase in serum total cholesterol and decrease in Low Density Lipoproteins (LDL) (SCHAEFER, 1997). Therefore, the SFA reduction observed in irradiated shrimp could be a nutritional advantage for consumers.

Stearic acid (18:0) was the predominant SFA found in irradiated shrimp. This fatty acid is a long-chain saturated fatty acid. However, in contrast with other saturated fatty acids, stearic acid is known to have a neutral effectson blood cholesterol concentrations. In the human organism, stearic acid is rapidly converted into oleic acid that has hypocholesterolemic effects (CASTRO et al., 2004).

As compared to non-irradiated shrimp, the total Monounsaturated Fatty Acids (MUFA) value was higher in shrimp irradiated with $6 \mathrm{kGy}$. For total MUFA, regression analysis indicated a quadratic effect $\left(\mathrm{R}^{2}=0.77\right)$. Thus, irradiation produced maximum reduction of MUFA at a dose of $2.19 \mathrm{kGy}$. Higher dose values provided increase of MUFA in shrimps (Table 2).

These results are in agreement with Erkan and Ozden (2007), who reported a reduction of MUFA with a low irradiation dose (2.5 kGy) and with a high irradiation dose (5.0 kGy) used on sea bream (Sparus aurata). 
Oleic acid (18:1) was the main MUFA present in the irradiated shrimp, and an increase in the concentration of this acid with high irradiation doses could be a nutritional advantage for consumers due to its hypocholesterolemic effect.

No effect of irradiation $(p>0.05)$ was found on total polyunsaturated fatty acids (PUFA) and on the PUFA/SFA ratio (Table 2). According to Kanatt, Chander and Sharma (2006), changes in PUFA content are minimized when irradiation is carried out under frozen $\left(-20^{\circ} \mathrm{C}\right)$ conditions.

The predominant PUFA found were linoleic, EPA, and DHA, which are omega 3 long chain PUFA. This fact was expected because seafood is considered a high source of omega 3 long chain PUFA, which are involved in the prevention of cardiovascular diseases (SIROT et al., 2008). Thus, the effect found in this study indicates that gamma irradiation could be used on frozen headed shrimp as a form of preservation because fewer alterations occurred in PUFA content.

Cholesterol values in irradiated samples were not different $(p>0.05)$ from those in non-irradiated shrimp (Table 2). The radiation process leads to oxidation of cholesterol. Free radicals generated by the process of lipid peroxidation co-oxidize several molecules, especially cholesterol which is in the lipid fraction and membranes of animal tissues. The production of cholesterol oxides has also been observed in shrimp that has been processed by others methods such as boiling or deep-frying (MOURA; TENUTA-FILHO, 2002). However, the lowering of cholesterol levels was not observed in the present study, probably due the frozen $\left(-20^{\circ} \mathrm{C}\right)$ condition of the samples during irradiation.

TBARS values were higher $(\mathrm{p}<0.05)$ in samples irradiated with 2, 4, and $6 \mathrm{kGy}$, as compared to non-irradiated samples (Table 3). These results are also in agreement with those found by several researchers who reported an increase of TBARS values after the irradiation of animal origin food such as dry-cured hams, shrimp, and lamb meat (CAVA et al., 2005; KANATT et al., 2006; KANATT; CHANDER; SHARMA, 2006). Moreover, regression analysis indicated a quadratic effect $\left(\mathrm{R}^{2}=0.63, \mathrm{p}<0.05\right)$ of irradiation on shrimp TBARS values which increased to a maximum with the dose value of $4.42 \mathrm{kGy}$ (Footnote, Table 3).

The increase in TBARS values after irradiation was small and should be related to the lipid oxidation induced by free radicals generated by irradiation. Slight changes in TBARS values were expected since irradiating shrimp in the frozen state may reduce chemical changes in food lipids (LAWRIE,
2005). Moreover, the low fat content of headed shrimp (about $1 \%)$ probably also contributed to the low degree of oxidation observed in this study.

Although TBARS values were higher in irradiated samples, these values are close to those considered as the acceptable limit for the consumption of foods. TBARS values of $0.6-2.0 \mathrm{mg} \mathrm{de}$ malondialdehyde. $\mathrm{kg}^{-1}$ values were found to be the threshold level at which unacceptable oxidation flavors were first detected by a non-trained sensorial panel (GREENE; CUMUZE, 1982). Cadun, Cakli and Kisla (2005) reported that shrimp can be considered with good quality when TBARS values are less than $3 \mathrm{mg}$ malondialdehyde. $\mathrm{kg}^{-1}$.

No effect of irradiation $(\mathrm{p}>0.05)$ was found on cooked shrimp lightness color component $\mathrm{L}^{*}$ (Table 3 ). However, color component $\mathrm{a}^{*}$ (redness) was higher $(\mathrm{p}<0.05)$ at the $6 \mathrm{kGy}$ dose as compared to that of the non-irradiated product. Color component $b^{*}$ (yellowness) increased in samples irradiated with the $6 \mathrm{kGy}$ dose as compared to those irradiated with 0 and $2 \mathrm{kGy}$.

These results were also in agreement with those found by several researchers who reported an increase of redness and yellowness after irradiation of animal origin food (CAVA et al., 2005; KIM et al., 2004; ZHU et al., 2003). However, Lopes (2006) who evaluated the synergic effect of gamma irradiation and refrigeration on the conservation of white shrimp (L. vannamei), did not observe significant changes in color components with irradiation.

Moreover, regression analysis indicated a linear increase $\left(\mathrm{R}^{2}=0.41, \mathrm{p}<0.05\right)$ of components color $\mathrm{a}^{*}$ and $\mathrm{b}^{*}$ with irradiation (Footnote of Table 3).

Table 3. TBARS values and color components $L^{\star}, a^{\star}$, and $b^{\star}$ of headed shrimp (P. vannamei) measured after freezing, packaging, and irradiating $\left({ }^{60} \mathrm{Co}\right)$ with 0,2 , 4 , or $6 \mathrm{kGy}$ doses ${ }^{(1)(2)}$.

\begin{tabular}{ccccc}
\hline $\begin{array}{c}\text { Dose } \\
(\mathrm{kGy})\end{array}$ & TBARS $^{(3)(4)}$ & $\begin{array}{c}\text { Color } \\
\text { component } \mathrm{L}^{*}\end{array}$ & $\begin{array}{c}\text { Color } \\
\text { component } \mathrm{a}^{\star(5)}\end{array}$ & $\begin{array}{c}\text { Color } \\
\text { component } \mathrm{b}^{\star(6)}\end{array}$ \\
\hline 0 & $0.16^{\mathrm{b}} \pm 0.02$ & $71.81 \pm 3.40 \mathrm{~A}$ & $7.17^{\mathrm{b}} \pm 0.72$ & $19.89^{\mathrm{b}} \pm 0.87$ \\
2 & $0.23^{\mathrm{a}} \pm 0.03$ & $70.60^{\mathrm{a}} \pm 1.34$ & $7.71^{\mathrm{ab}} \pm 1.00$ & $20.05^{\mathrm{b}} \pm 0.66$ \\
4 & $0.23^{\mathrm{a}} \pm 0.03$ & $70.54^{\mathrm{a}} \pm 1.74$ & $8.17^{\mathrm{ab}} \pm 0.64$ & $21.11^{\mathrm{ab}} \pm 0.89$ \\
6 & $0.23^{\mathrm{a}} \pm 0.02$ & $69.68^{\mathrm{a}} \pm 0.44$ & $9.11^{\mathrm{a}} \pm 1.27$ & $21.95^{\mathrm{a}} \pm 1.55$ \\
\hline
\end{tabular}

${ }^{(1)}$ Mean values with different letters within a column are significantly different $(\mathrm{p}<0.05)$ by SNK test, $\mathrm{n}=5$; ${ }^{(2)}$ TBARS determined on raw shrimp samples. Color measured on cooked samples; ${ }^{(3)} \mathrm{mg}$ malondialdehyde. $\mathrm{kg}^{-1}$ of raw headed shrimp; ${ }^{(4)}$ Quadratic effect $\left(y=0.16+0.03 x-0.004 x^{2} ; R^{2}=0.63\right) ;{ }^{(5)}$ Linear effect $\left(y=7.09+0.31 x ; R^{2}=0.41\right) ;{ }^{(6)}$ Linear effect $\left(y=19.66+0.36 x ; R^{2}=0.41\right)$.

Table 2. Saturated Fatty Acid (SFA), Monounsaturated Fatty Acid (MUFA), Polyunsaturated Fatty Acid (PUFA), PUFA/SFA ratio, and cholesterol of headed shrimp (P. vannamei) measured after freezing, packaging, and irradiating $\left({ }^{60} \mathrm{Co}\right)$ with $0,2,4$, or $6 \mathrm{kGy}$ doses ${ }^{(1)}$.

\begin{tabular}{cccccc}
\hline Dose $(\mathrm{kGy})$ & SFA $^{(2)}(\%)$ & MUFA $^{(3)}(\%)$ & PUFA (\%) & PUFA/ SFA ratio (\%) & Cholesterol (mg.100 g $\left.{ }^{-1}\right)$ \\
\hline 0 & $65.29^{\mathrm{ab}} \pm 1.25$ & $9.68^{\mathrm{b}} \pm 0.59$ & $15.31^{\mathrm{a}} \pm 0.78$ & $0.23^{\mathrm{a}} \pm 0.01$ & $121.14^{\mathrm{ab}} \pm 23.74$ \\
2 & $67.44^{\mathrm{a}} \pm 1.88$ & $7.76^{\mathrm{b}} \pm 1.39$ & $14.23^{\mathrm{a}} \pm 0.98$ & $0.21^{\mathrm{a}} \pm 0.02$ & $118.05^{\mathrm{ab}} \pm 6.01$ \\
4 & $63.20^{\mathrm{b}} \pm 1.57$ & $9.01^{\mathrm{b}} \pm 1.56$ & $12.69^{\mathrm{a}} \pm 2.85$ & $0.20^{\mathrm{a}} \pm 0.04$ & $140.27^{\mathrm{a}} \pm 15.22$ \\
6 & $63.03^{\mathrm{b}} \pm 2.24$ & $13.71^{\mathrm{a}} \pm 1.66$ & $16.56^{\mathrm{a}} \pm 3.14$ & $0.26^{\mathrm{a}} \pm 0.06$ & $112.96^{\mathrm{b}} \pm 4.69$ \\
\hline
\end{tabular}

${ }^{(1)}$ Mean values with different letters within a column are significantly different $(\mathrm{p}<0.05)$ by SNK test, $\mathrm{n}=5$; ${ }^{(2)} \mathrm{Quadratic}$ effect $\left(\mathrm{y}=65.81+0.32 \mathrm{x}-0.14 \mathrm{x}^{2} ; \mathrm{R}^{2}=0.32\right)$, being $\mathrm{y}=$ sum of saturated fatty acids; $x=$ irradiation dose; $R^{2}=$ determination coefficient; ${ }^{(3)}$ Quadratic effect $\left(y=9.69+1.82 x-0.41 x^{2} ; R^{2}=0.77\right)$. 


\section{Conclusions}

Gamma irradiation with ${ }^{60} \mathrm{Co}$ applied to frozen and packaged headed shrimp in doses of up to $6 \mathrm{kGy}$ does not compromise negatively the fatty acid composition, cholesterol content, and lipid stability of the product. Irradiation increases the redness and yellowness of the surface color of cooked shrimp, but it does not alter its lightness.

\section{Acknowledgments}

The authors are grateful to Centro de Desenvolvimento da Tecnologia Nuclear - CDTN, Belo Horizonte - MG, Brazil, for their technical assistance irradiating shrimp samples.

\section{References}

ALFAIA, C. M. M. et al. Irradiation effect on fatty acid composition and conjugated linoleic acid isomers in frozen lamb meat. Meat Science, v. 77, n. 4, p. 689-695, 2007.

BARBIERI JÚNIOR, R. C.; OSTRENSKY NETO, A. Camarões marinhos: engorda. Viçosa, MG: Aprenda Fácil, 2002. 370 p.

BOTSOGLOU, N. A. et al. Yolk fatty acid composition and cholesterol conten in resnponse to level and form of dietary flaxseed. Journal of Agricultural and Food Chemistry, v. 46, n. 11, p. 4652-4656, 1998.

BRASIL. Ministério da Agricultura, Pecuária e Abastecimento. Departamento de Pesca e Aquicultura. Plataforma tecnológica do camarão marinho cultivado. Brasília, DF: 2001. 276 p.

CADUN, A.; CAKLI, S.; KISLA, D. A study of marination of deepwater pink shrimp (Parapenaeus longirostris, Lucas, 1846) and its shelf life. Food Chemistry, v. 90, n. 1-2, p. 53-59, 2005.

CARVALHO, J. M. M. et al. Perspectivas para o desenvolvimento da carcinicultura no nordeste brasileiro. Fortaleza: Banco do Nordeste do Brasil, 2005. 132 p. (Série documentos do ETENE, n. 2).

CASTRO, L. C. V. et al. Nutrição e doenças cardiovasculares: os marcadores de risco em adultos. Revista de Nutrição, v. 17, n. 3, p. 369-377, 2004.

CAVA, R. et al. Effect of irradiation on colour and lipid oxidation of dry-cured hams from free-range reared and intensively reared pigs. Innovative Food Science and Emerging Technologies, v. 6, n. 2, p. 135-144, 2005.

CHEN, Y. J. et al. Effect of low dose gamma irradiation on beef quality and fatty acid composition of beef intramuscular lipid. Meat Science, v. 75, n. 3, p. 423-431, 2007.

ERKAN, N.; OZDEN, O. The changes of fatty acid and amino acid compositions in sea bream (Sparus aurata) during irradiation process. Radiation Physics and Chemistry, v. 76, n. 10, p. 1636-1641, 2007.

FACCO, E. M. P. Parâmetros de qualidade do charque relacionados ao efeito da suplementação de vitamina $\mathrm{E}$ na dieta de bovinos de raça Nelore em confinamento. Dissertação (Mestrado em Ciência de Alimentos)-Faculdade de Engenharia de Alimentos, Universidade Estadual de Campinas, Campinas, 2002.

GREENE, B. E.; CUMUZE, T. H. Relationship between TBA numbers and inexperienced panelists assessments of oxidized flavor in cooked beef. Journal of Food Science, v. 47, n. 1, 52-54, 1982.

KANATT, S. R. et al. Development of shelf-stable, ready-to-eat (RTE) shrimps (Penaeus indicus) using $\gamma$-radiation as one of the hurdles.
LWT - Food Science and Technology, v. 39, n. 6, p. 621-626, 2006.

KANATT, S. R.; CHANDER, R.; SHARMA, A. Effect of radiation processing of lamb meat on its lipids. Food Chemistry, v. 97, n. 1, p. 80-86, 2006.

KIM, J. H. et al. Color, flavor, and sensory characteristics of gammairradiated salted and fermented anchovy sauce. Radiation Physics and Chemistry, v. 69, n. 2, p. 179-187, 2004.

LAKSHMANAN, R. et al. Stability of lipids of Indian mackerel to gamma irradiation. Journal of Food Lipids, v. 6, n. 4, p. 277-285, 1999.

LAWRIE, R. A. Ciência da carne. 6. ed. Porto Alegre: Artmed, 2005. $384 \mathrm{p}$.

LOPES, T. G. G. Efeito sinergístico da radiação gama e da refrigeração na conservação do camarão-branco-do-pacífico (Litopenaeus vannamei). 2006. 94 f. Dissertação (Mestrado em Ciência e Tecnologia de Alimentos)-Escola Superior de Agricultura Luiz de Queiroz, Universidade de São Paulo, Piracicaba, 2006.

MINOLTA Co. Precise color communication - color control from perception to instrumentation. Osaka: Minolta, 1998. 59 p.

MOURA, A. F. P.; TENUTA-FILHO, A. Efeito do processamento sobre os níveis de colesterol e 7-cetocolesterol em camarão-rosa. Ciência e Tecnologia de Alimentos, v. 22, n. 2, p. 117-121, 2002.

NAM, K. C. et al. Cholesterol oxidation products in irradiated raw meat with different packaging and storage time. Meat Science, v. 58, n. 4 , p. $431-435,2001$.

PEREZ-VELAZQUEZ, M. et al. Changes in lipid class and fatty acid composition of adult male Litopenaeus vannamei (Boone) in response to culture temperature and food deprivation. Aquaculture Research, v. 34, n. 13, p. 1205-1213, 2003.

RAHARJO, S.; SOFOS, J. N.; SCHMIDT, G. R. Improved speed, specificity, and limit of determination of aqueous acid extraction thiobarbituric acid- $\mathrm{C}_{18}$ method for measuring lipid peroxidation in beef. Journal of Agricultural and Food Chemistry, v. 40, n. 11, p. 2182-2185, 1992.

RULE, D. C. et al. Comparison of muscle fatty acid profiles and cholesterol concentrations of bison, beef cattle, elk, and chicken. Journal Animal Science, v. 80, n. 5, p. 1202-1211, 2002.

SANTOS, A. F. et al. Determinação da dose de irradiação gama para reduzir a população de Salmonella spp em carne de frango. Ciência e Tecnologia de Alimentos, v. 23, n. 2, p. 200-205, 2003.

SCHAEFER, E. J. Effect of dietary fatty acids on lipoproteins and cardiovascular disease risk: summary. American Journal of Clinical Nutrition, v. 65, n. 5, p. 1655-1656, 1997.

SIROT, V. et al. Lipid and fatty acid composition of fish and seafood consumed in France: CALIPSO study. Journal of Food Composition and Analysis, v. 21, n. 1, p. 8-16, 2008.

STATISTICAL ANALYSIS SYSTEM. SAS/STAT: user's guide. Version 6. 12. ed. Cary: SAS Institute, 2000.

VENUGOPAL, V.; DOKE, S. N.; THOMAS, P. Radiation processing to improve the quality of fishery products. Critical Reviews in Food Science and Nutrition, v. 39, n. 5, p. 391-440, 1999.

YILMAZ, I.; GEÇGEL, U. Effects of gamma irradiation on trans fatty acid composition in ground beef. Food Control, v. 18, n. 6, p. 635-638, 2007.

ZHU, M. J. et al. Effect of irradiation on the quality of turkey ham during storage. Meat Science, v. 66, n. 1, p. 63-68, 2003. 